\title{
Cytotoxicity of four Aframomum species (A. arundinaceum, A. alboviolaceum, A. kayserianum and $A$. polyanthum) towards multi-factorial drug resistant cancer cell lines
}

Victor Kuete ${ }^{1,3^{*}}$, Patrick Y Ango ${ }^{2}$, Samuel O Yeboah ${ }^{4}$, Armelle T Mbaveng ${ }^{3}$, Renameditswe Mapitse ${ }^{4}$, Gilbert DWF Kapche ${ }^{5}$, Bonaventure T Ngadjui ${ }^{4}$ and Thomas Efferth ${ }^{1 *}$

\begin{abstract}
Background: The search for natural products as potential cytotoxic agents has yielded promising candidates. However multidrug resistance (MDR) is still a major hurdle for patients receiving chemotherapy. In the present study, we evaluated the cytotoxicity of the methanol extracts of four dietary Aframomum plant species (A. arundinaceum, A. alboviolaceum, A. kayserianum and A. polyanthum) against nine sensitive and MDR cancer cell lines. We have also identified the bioactive constituents of $A$. arundinaceum.

Methods: The cytotoxicity of the methanol extracts of the above plants was determined using a resazurin reduction assay. Chromatographic techniques were used to isolate the constituents of $A$. arundinaceum.

Results: A preliminary experiment on leukemia CCRF-CEM cells at $40 \mu \mathrm{g} / \mathrm{mL}$ showed that the extracts from $A$. kayserianum and $A$. alboviolaceum as well as the isolated compounds namely compounds aframodial (1), 8 (17),12-labdadien-15,16-dial (2), galanolactone (3), 1-p-menthene-3,6-diol (6) and 1,4-dimethoxybenzene (7) were less active, inducing more than $50 \%$ growth of this cell line contrary to A. polyanthum and A. arundinaceum extracts, galanals A (4) and B (5), naringenin (8) and kaempferol-3,7,4'-trimethylether (9). The $I C_{50}$ values below or around $30 \mu \mathrm{g} /$ $\mathrm{mL}$ were recorded with $A$. arundinaceum extract against eight of the nine tested cancer cell lines. This extract as well as compound 8 displayed $I_{50}$ values below $40 \mu \mathrm{g} / \mathrm{mL}$ towards the nine tested cancer cell lines whilst $A$. polyanthum extract, compounds $\mathbf{4}, 5$ and $\mathbf{9}$ showed selective activities. Collateral sensitivity (hypersensitivity) was observed with A. arundinaceum extract towards leukemia CEM/ADR5000 cells and glioblastoma U87MG.4EGFR compared to their respective sensitive counterparts CEM/CEM and U87MG.

Conclusion: The results of this study provide evidence of the cytotoxicity selected Aframomum species as well as a baseline information for the potential use of Aframomum arundinaceum in the fight against drug sensitive and otherwise drug-resistant cancers.
\end{abstract}

Keywords: Aframomum, Cameroon, Cancer, Cytotoxicity, Multidrug resistant, Zingiberaceae

\footnotetext{
*Correspondence: kuetevictor@yahoo.fr; efferth@uni-mainz.de

'Department of Pharmaceutical Biology, Institute of Pharmacy and Biochemistry, University of Mainz, 55128 Mainz, Germany

Full list of author information is available at the end of the article
} 


\section{Background}

Chemotherapy remains the major treatment of cancers but often fails due to cells multidrug resistance (MDR) $[1,2]$. MDR is displayed by many cancer cells to withstand increasingly higher doses of antineoplastic compounds [3]. Investigation for naturally occurring molecules as potential cytotoxic drugs has yielded promising candidates [3-7]. However, MDR is still considered a major hurdle for patients receiving chemotherapy $[8,9]$. Various Cameroonian dietary plants including those from the family Zinziberaceae are used in traditional medicine to manage various ailments [5,10-13]. The genus Aframomum, belonging to the Zingiberaceae family have 40 species and is most common in tropical and subtropical regions [14]. Twenty species are found in Cameroon, where they are widely used as spices and in traditional medicine [14]. The Seeds of Aframomum arundinaceum K. Schum are used as laxative and as anti-helmintic. The fresh juice of the rhizomes is used against body odor. The rhizomes are used against toothache and the crushed seeds against fungal infections [10]. The decoction of the leaves Aframomum melegueta K. Schum together with the leaves of Momordica charantia and Sorghum arundinaceum cereal in local dry gin (alcohol) is recommended to be taken one dose daily against cholera [15]. Several Aframomum species such as Aframomum angustifolium, A. danielli, A. sanguineum, and A. sulcatum are also traditionally used to treat fevers in Africa [16], and recently, the antiplasmodial activity of some labdanes from A. sceptrum and A. latifolium was demonstrated [17]. The antibacterial activities of Aframomum kayserianum [12] and Aframomum polyanthum [13] were also reported on Gram-negative multidrug-resistant phenotypes. The cytotoxicity of other Afromomum species such as A. citratum and $A$. melegueta towards leukemia CCRF-CEM and ADR5000 cell lines was also reported [5]. The present study was designed to investigate the cytotoxicity of four dietary Aframomum species commonly used as spices in Cameroon, Aframomum alboviolaceum (Ridl.) K. Schum, A. arundinaceum (Oliver \& Hanbury) K. Schum, Aframomum kayserianum K. Schum and Aframomum polyanthum K. Schum towards sensitive and multi-factorial drug resistant cancer cell lines. The study was extended to the identification of the bioactive constituents of A. arundinaceum.

\section{Methods}

\section{Plant material and extraction}

The tested Aframomum species, A. alboviolaceum, A. kayserianum and $A$. polyanthum were purchased from Bafoussam local market (West region of Cameroon) in January 2012. Aframomum arundinaceum was collected in Yaoundé (Centre region) in March 2012. The plants were further identified at the National Herbarium
(Yaoundé, Cameroon) where voucher specimens were deposited under the reference numbers 11704/SFR/ CAM (A. arundinaceum), 34888/HNC (A. alboviolaceum), 18884/SRFC (A. kayserianum) and 3981/SRFK (A. polyanthum). The air dried fruits of $A$. kayserianum, A. polyanthum (100 g) and A. arundinaceum (3000 g) as well as the roots of $A$. alboviolaceum (100 g) were powdered and macerated with methanol for $48 \mathrm{~h}$ at room temperature. The methanol extract was concentrated in vacuo to give $18.7 \mathrm{~g}, 21.2 \mathrm{~g}, 25.3$ and $100 \mathrm{~g}$ of the crude extracts of $A$. kayserianum, A. polyanthum, A. alboviolaceum and $A$. arundinaceum respectively. The extracts were then conserved at $4^{\circ} \mathrm{C}$ until further use.

Isolation of compounds from Aframomum arundinaceum Crude extract of $A$. arundinaceum (100 g) was successively extracted with petroleum ether, chloroform and methanol at room temperature. The petroleum ether fraction (25 g) was column chromatographed on $100 \mathrm{~g}$ of silica gel (Merck, 0.040-0.063 mm) using hexane and hexane-choloroform mixture with increasing polarity. Fractions of $300 \mathrm{~mL}$ were collected, concentrated, and pooled on the basis of their thin layer chromatography (TLC) profile. The obtained fractions (frs) directly afforded a yellow oil (1; frs 4 to 9; $30 \mathrm{mg}$ ) and amorphous powders 2 ( frs 13 to 16; $25 \mathrm{mg}$ ), 3 (frs 20 to 27; $40 \mathrm{mg}$ ), 4 (frs 30 to 33 ) and 5 (frs 36 to $38 ; 10 \mathrm{mg}$ ). The chloroform extract (20 g) was also column chromatographed on $250 \mathrm{~g}$ of silica gel (Merck, 0.040-0.063 mm) using hexane (Hex) and mixture of hexane-chloroform $\left(\mathrm{Hex}-\mathrm{CHCl}_{3}\right)$. Fractions of $400 \mathrm{~mL}$ were collected, concentrated and pooled after TLC analysis to give five subfractions (sub-frs A-E).

Sub-fraction $\mathrm{B}\left(\mathrm{Hex}-\mathrm{CHCl}_{3} ; 10\right.$ to $25 ; 6 \mathrm{~g}$ ) was subjected to column chromatography $(\mathrm{CC})$ to afford a white crystal $(6 ; 20 \mathrm{mg})$. Sub-fraction C (8.0 g) obtained with Hexane- $\mathrm{CHCl}_{3}$ 4:6 was subjected to $\mathrm{CC}$ (silica gel 60, $50 \mathrm{~g}$ ) and eluted with $\mathrm{Hex}-\mathrm{CHCl}_{3}$ mixtures of increasing polarity to give 6 new sub-fractions $\left(C_{1}-C_{6}\right)$. Subfraction $\mathrm{C}_{4}$ obtained with $\mathrm{Hex}-\mathrm{CHCl}_{3}$ 6:4. afforded a yellow oil $(7 ; 10 \mathrm{mg})$. Sub-fraction $\mathrm{C}_{5}\left(\mathrm{Hex}-\mathrm{CHCl}_{3} 4: 6\right)$ and $\mathrm{C}_{6}$ ( $\mathrm{Hex}-\mathrm{CHCl}_{3}$ 8:2) were repeatedly filtered through Sephadex $\mathrm{LH}-20 \quad\left(\mathrm{CHCl}_{3}-\mathrm{MeOH} \quad 7: 3\right)$ to give yellow powders, 8 (sub-frs 3 to $6 ; 10.0 \mathrm{mg}$ ) and 9 (sub-frs 15 to $19 ; 15 \mathrm{mg})$.

\section{General procedure}

Aluminum sheet pre-coated with silica gel $60 F 254 \mathrm{~nm}$ (Merck) was used for thin layer chromatography; the spots were visualized using both ultraviolet light (254 and $366 \mathrm{~nm}$ ) and $50 \% \mathrm{H}_{2} \mathrm{SO}_{4}$ spray reagent. NMR spectra were recorded on a Bruker Avance 300 (Billerica, 
MA, USA) at $300 \mathrm{MHz}\left({ }^{1} \mathrm{H}\right)$ and $75 \mathrm{MHz}\left({ }^{13} \mathrm{C}\right)$, with the residual solvent peaks as internal references. Mass spectra were recorded with API QSTAR pulsar mass (Milford, MA, USA). Melting points (m.p) were recorded using a Stuart Scientific (Redhill, Surrey, UK) melting point apparatus (SMP1) and are uncorrected. The chemical structures of the compounds were confirmed by comparing with reference data from available literature (Figure 1).

\section{Chemicals}

Doxorubicin $98.0 \%$ were provided by the University Pharmacy of the Johannes Gutenberg University (Mainz, Germany) and dissolved in PBS (Invitrogen, Eggenstein, Germany) at a concentration of $10 \mathrm{mM}$. Geneticin $>98 \%$ (72.18 mM; Sigma-Aldrich, Munich, Germany).

\section{Cell cultures}

The cell lines used the present work, their origins and their treatments were previously reported $[18,19]$. They include drug-sensitive CCRF-CEM and multidrug-resistant P-glycoprotein over-expressing CEM/ADR5000 leukemia cells [20-22], the MDA-MB-231-pcDNA3 breast cancer cells and its resistant subline MDA-MB-231-BCRP clone 23) [23], the HCT116 $\left(p 53^{+/+}\right)$colon cancer cells and its knockout clones HCT116 $\left(p 53^{-/}\right)$, the U87MG glioblastoma cells and its resistant subline U87MG. $\triangle E G F R$, HepG2 hepatocarcinoma cells and AML12 normal hepatocytes $[6,19,24]$. The CCRF-CEM and CEM/ADR5000 leukemia cells were maintained in RPMI 1640 medium (Invitrogen) supplemented with $10 \%$ fetal calf serum in a humidified $5 \% \mathrm{CO}_{2}$ atmosphere at $37^{\circ} \mathrm{C}$. Sensitive and resistant cells were kindly provided by Dr. Axel Sauerbrey (Department of Pediatrics, University of Jena, Jena,<smiles>CC1(C)CCC[C@]2(C)[C@@H](C/C=C(/C=O)CC=O)[C@]3(CC[C@]12C)CO3</smiles><smiles></smiles><smiles>Oc1ccc(O)cc1</smiles><smiles>C=C1CC[C@]2([C@@H](C)CCCC2(C)C)[C@@H](/C=C(/CC=O)C(=O)O)CC1=C</smiles><smiles>CC1(C)CCC[C@]2(C)[C@@H]3CC=C(C=O)C[C@H](O)[C@@]3(C=O)CC[C@]12C</smiles><smiles>CC1=C[C@@H](O)[C@H](O)C[C@H]1C(C)C</smiles>
6<smiles>O=C1CC(c2ccc(O)cc2)Oc2cc(O)cc(O)c21</smiles><smiles>COc1ccc(-c2oc3cc(OC)cc(O)c3c(=O)c2OC)cc1</smiles>

Figure 1 Chemical structures of compounds isolated from the fruit of Aframomum arundinanceum K Schum. 1: aframodial; 2: 8(17), 12-labdadien-15,16-dial; 3: galanolactone; 4: galanal A; 5: galanal B; 6: 1-p-menthene-3,6-diol; 7: 1,4-dihydroxybenzene; 8: naringenin; 9: kaempferol-3,7,4'-trimethylether. 
Germany). The generation of the resistant subline was previously described $[6,19,24]$. Breast cancer cells, transduced with control vector (MDA-MB-231-pcDNA3) or with CDNA for the breast cancer resistance protein $B C R P$ (MDA-MB-231-BCRP clone 23), were maintained under standard conditions as described above for CCRF-CEM cells. Human wild-type HCT116 $\left(p 53^{+/+}\right)$colon cancer cells as well as knockout clones HCT116 ( $\left.p 53^{-/-}\right)$derived by homologous recombination were a generous gift from Dr. B. Vogelstein and H. Hermeking (Howard Hughes Medical Institute, Baltimore, MD). Human glioblastoma multiforme U87MG cells (non-transduced) and U87MG cell line transduced with an expression vector harboring an epidermal growth factor receptor (EGFR) gene with a genomic deletion of exons 2 through 7 (U87MG. $\triangle E G F R$ ) were kindly provided by Dr. W. K. Cavenee (Ludwig Institute for Cancer Research, San Diego, CA). MDA-MB-231-BCRP, U87MG. $\triangle E G F R$ and HCT116 ( $p 53^{-/-}$) were maintained in DMEM medium containing 10\% FBS (Invitrogen) and 1\% penicillin (100 $\mathrm{U} / \mathrm{mL}$ )-streptomycin $(100 \mu \mathrm{g} / \mathrm{mL})$ (Invitrogen) and were continuously treated with $800 \mathrm{ng} / \mathrm{mL}$ and $400 \mu \mathrm{g} / \mathrm{mL}$ geneticin, respectively. Human HepG2 hepatocellular carcinoma cells and normal AML12 heptocytes were obtained from the American Type Culture Collection (ATCC, USA). The above medium without geneticin was used to maintain MDA-MB-231, U87MG, HCT116 $\left(p 53^{+/+}\right)$, HepG2 and AML12 cell lines. The cells were passaged twice weekly. All experiments were performed with cells in the logarithmic growth phase.

\section{Resazurin reduction assay}

The cytotoxicity of the studied samples was performed by resazurin reduction assay as we previously described $[6,18,19,24-26]$. Briefly, adherent cells at $1 \times 10^{4}$ cells were allowed to attach overnight and then treated with different studied samples. Samples were preliminary tested at $40 \mu \mathrm{g} / \mathrm{mL}$ (extract and isolated compounds) and doxorubicin $(20 \mu \mathrm{g} / \mathrm{mL})$ against the sensitive leukemia CCRFCEM cell line and those inducing less than $50 \%$ growth proliferation were further tested for $\mathrm{IC}_{50}$ determinations towards all the studied cell lines. For suspension cells, aliquots of $2 \times 10^{4}$ cells per well were seeded in 96-wellplates in a final volume of $200 \mu \mathrm{L}$. Extracts and compounds were prior diluted in DMSO and tested in a final concentration below $0.1 \%$ (A final concentration of $0.1 \%$ DMSO was used as negative control and did not show any effect on cell growth). The tested concentrations ranges were $0.16 \mu \mathrm{g} / \mathrm{mL}$ to $40 \mu \mathrm{g} / \mathrm{mL}$ for crude extracts and isolated compounds and $0.08 \mu \mathrm{g} / \mathrm{mL}$ to $20 \mu \mathrm{g} / \mathrm{mL}$ for doxorubicin. After $72 \mathrm{~h}$ incubation and a resazurin (Sigma-Aldrich, Schnelldorf, Germany) staining, fluorescence was measured on an Infinite M2000 Pro $^{\mathrm{Tm}}$ plate reader (Tecan, Crailsheim, Germany) using an excitation wavelength of $544 \mathrm{~nm}$ and an emission wavelength of $590 \mathrm{~nm}$. Each assay was done at least two times, with six replicates each. $\mathrm{IC}_{50}$ values represent the sample's concentrations required to inhibit $50 \%$ of cell proliferation and were calculated from a calibration curve by linear regression using Microsoft Excel [5,6].

\section{Results and discussion}

The structures of the compounds isolated from Aframomum arundinaceum were established using spectroscopic analysis, especially, NMR spectra in conjunction with 2D experiments, COSY, HMQC, HMBC, and direct comparison with published information and with authentic specimens obtained in our research group for some cases. The compounds isolated from the fruits of A. arundinaceum (Figure 1) were identified as Aframodial $\mathrm{C}_{20} \mathrm{H}_{30} \mathrm{O}_{3}$ (1; m/z 318.2) [27], 8(17),12-labdadien15,16-dial $\mathrm{C}_{20} \mathrm{H}_{30} \mathrm{O}_{2}(2 ; \mathrm{m} / \mathrm{z}$ 302.2) [17], galanolactone $\mathrm{C}_{20} \mathrm{H}_{30} \mathrm{O}_{3}$ (3; m/z 318.2) [27], galanal $\mathrm{A} \mathrm{C}_{20} \mathrm{H}_{30} \mathrm{O}_{3}$ (4; $15 \mathrm{mg}, \mathrm{m} / \mathrm{z}$ 318.2) [28], and galanal $\mathrm{B} \mathrm{C}_{20} \mathrm{H}_{30} \mathrm{O}_{3}(5 ; \mathrm{m} / \mathrm{z}$ 318.2) [29], 1-p-menthene-3,6-diol $\mathrm{C}_{10} \mathrm{H}_{18} \mathrm{O}_{2}$ (6; m/z 170.1; m.p:165-167 ${ }^{\circ} \mathrm{C}$ ) [30], 1,4-dihydroxybenzene $\mathrm{C}_{6} \mathrm{H}_{6} \mathrm{O}_{2}$ (7; $\mathrm{m} / \mathrm{z}$ 110.0) [31], naringenin $\mathrm{C}_{15} \mathrm{H}_{12} \mathrm{O}_{5}$ (8; m/z 272.0; $245-248^{\circ} \mathrm{C}$ ) [32] and kaempferol-3,7,4'-trimethylether $\mathrm{C}_{18} \mathrm{H}_{16} \mathrm{O}_{6}\left(9 ; \mathrm{m} / \mathrm{z} 328.0 ; 157-158^{\circ} \mathrm{C}\right)$ [33]. The cytotoxicity of compounds 1-9 as well as the crude extracts was determined towards drug sensitive and resistant cancer cell lines.

In a preliminary investigation of the four studied Aframomum species and compounds isolated from $A$. arundinaceum, we tested a single concentration of $40 \mu \mathrm{g} / \mathrm{mL}$ for each sample and $20 \mu \mathrm{g} / \mathrm{mL}$ for doxorubicin against the sensitive CCRF-CEM leukemia cell line (Figure 2). The extracts from A. kayserianum and A. alboviolaceum were less active and induced respectively $50.33 \%$ and $54.36 \%$ growth proliferation of CCRF-CEM cells. Compounds 1, 2, 3, 6 and 7 also induced more than 50\% growth of this cell line. The extracts from $A$. polyanthum (36.28\%) and $A$. arundinaceum (24.68\%) as well as compounds $\mathbf{4}$ (47.78\%), 5 (49.81\%), 8 (38.49\%) and 9 (39.58\%) displayed less than $50 \%$ growth proliferation of CCRF-CEM cells. The $\mathrm{IC}_{50}$ values of the above samples were further determined on nine cancer cell lines, including both sensitive and MDR phenotypes (Table 1). Aframomum. arundinaceum extract as well as compound 8 and doxorubucin induced less than $50 \%$ proliferation of all tested cancer cell lines, with $\mathrm{IC}_{50}$ values below $40 \mu \mathrm{g} / \mathrm{mL}$. A. polyanthum extract, compounds $\mathbf{9}$, 4 and 5 showed selective activities, the $\mathrm{IC}_{50}$ values $<40 \mu \mathrm{g} / \mathrm{mL}$ being obtained on $5 / 9,4 / 9,2 / 9$ and $1 / 9$ tested cell lines respectively (Table 1$)$. According to the National Cancer Institute (USA), $30 \mu \mathrm{g} / \mathrm{mL}$ is the upper $\mathrm{IC}_{50}$ limit considered promising for purification of a crude extract [34]. We therefore, tested a slightly higher 


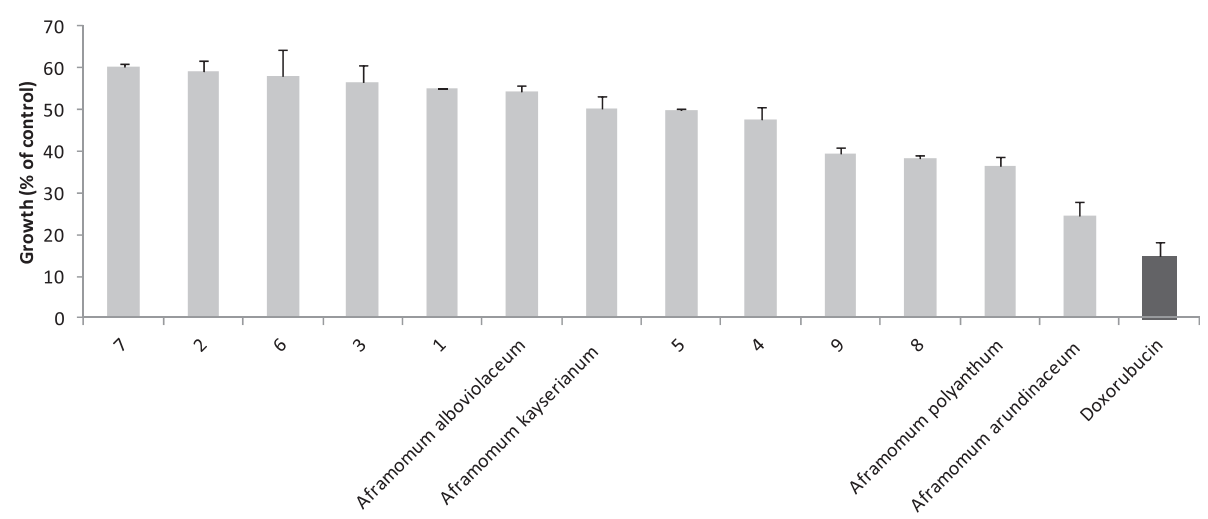

Figure 2 Growth percentage (\%) of leukemia CCRF-CEM cancer cell line treated with plant extracts and isolated compounds at $40 \mu \mathrm{g} /$ $\mathbf{m L}$ and doxorubicin $(\mathbf{2 0} \mathbf{\mu g} / \mathbf{m L})$. 1: aframodial; 2: 8(17),12-labdadien-15,16-dial; 3: galanolactone; 4: galanal A; 5: galanal B; 6: 1-p-menthene-3, 6-diol; 7: 1,4-dihydroxybenzene; 8: naringenin; 9: kaempferol-3,7,4'-trimethylether.

concentration of $40 \mu \mathrm{g} / \mathrm{mL}$ in our preliminary assay. Also, the $\mathrm{IC}_{50}$ threshold value of $4 \mu \mathrm{g} / \mathrm{ml}$ or $10 \mu \mathrm{M}[35,36]$ after 48 and $72 \mathrm{~h}$ incubations has been set to identify good cytotoxic compounds. Considering these thresholds, the $\mathrm{IC}_{50}$ values below or around $30 \mu \mathrm{g} / \mathrm{mL}$ were recorded with A. arundinaceum extract against eight of the nine tested cancer cell lines (Table 1) explaining why it was considered further for purification. Nonetheless, the extract from A. polyanthum also showed activities with $\mathrm{IC}_{50}$ values $<30 \mu \mathrm{g} / \mathrm{mL}$ on four of the nine tested cancer cell lines. Though Compound $\mathbf{8}$ was active on all the tested cancer cell lines, no $\mathrm{IC}_{50}$ below $4 \mu \mathrm{g} / \mathrm{ml}$ was recorded, the lowest values being $7.86 \mu \mathrm{g} / \mathrm{mL}$ against CEM/ADR5000 cells.
Interestingly, none of the selected extracts and compounds was more toxic towards AML12 normal hepatocytes $\left(\mathrm{IC}_{50}>40 \mathrm{Mg} / \mathrm{mL}\right)$ than cancer cell lines, suggesting their good selectivity. Importantly, collateral sensitivity (hypersensitivity) was also observed with $A$. arundinaceum extract towards CEM/ADR5000 cells (degree of resistance of 0.76) and U87MG. $\triangle E G F R$ (degree of resistance of 0.95) compared to their respective sensitive counterparts CEM/CEM and U87MG. This extract was also more active against hepatocarcinoma HepG2 as compared to AML12 normal hepatocytes, confirming its selectivity to cancer cells (Table 1). Despite the fact that compound $\mathbf{8}$ showed moderate activities, it also

Table 1 Cytotoxicity of the studied Aframomum extracts, compounds and doxorubicin towards sensitive and drug-resistant cancer cell lines and normal cells as determined by the resazurin assay

\begin{tabular}{|c|c|c|c|c|c|c|c|}
\hline \multirow[t]{3}{*}{ Cell lines } & \multicolumn{7}{|c|}{ Studied samples, $\mathrm{IC}_{50}$ values $(\mu \mathrm{g} / \mathrm{mL})^{\mathrm{a}}$ and degree of resistance (in braket) } \\
\hline & \multicolumn{2}{|c|}{ Aframomum species } & \multicolumn{4}{|c|}{ Compounds from A. arundinaceum } & \multirow[t]{2}{*}{ Doxorubucin } \\
\hline & A. polyanthum & A. arundinaceum & 4 & 5 & 8 & 9 & \\
\hline CCRF-CEM & $20.37 \pm 3.10$ & $18.08 \pm 0.98$ & $17.32 \pm 1.96$ & $\begin{array}{l}19.81 \pm \\
2.01\end{array}$ & $12.20 \pm 1.87$ & $18.38 \pm 2.04$ & $0.11 \pm 0.01$ \\
\hline CEM/ADR5000 & $28.16 \pm 1.24(1.38)$ & $13.73 \pm 1.02(0.76)$ & $-(>2.31)$ & $-(>2.02)$ & $7.86 \pm 0.74(0.64)$ & $18.22 \pm 1.18(0.99)$ & $\begin{array}{l}195.12 \pm 14.30 \\
(1772)\end{array}$ \\
\hline MDA-MB-231 & $33.79 \pm 2.38$ & $29.98 \pm 1.86$ & - & - & $9.51 \pm 1.03$ & - & $1.10 \pm 0.01$ \\
\hline $\begin{array}{l}\text { MDA-MB-231- } \\
\text { BCRP }\end{array}$ & $30.24 \pm 2.18(0.89)$ & $30.66 \pm 3.17(1.02)$ & $\begin{array}{l}27.99 \pm 2.39 \\
(<0.70)\end{array}$ & - & $18.12 \pm 2.01$ & $\begin{array}{l}33.14 \pm 2.64 \\
(<0.83)\end{array}$ & $7.83 \pm 0.01(7.11)$ \\
\hline HCT116 p 53 $3^{+/+}$ & - & $23.06 \pm 2.21$ & - & - & $13.65 \pm 1.11$ & - & $1.43 \pm 0.02$ \\
\hline HCT116 p53 & - & $27.38 \pm 1.92(1.19)$ & - & - & $13.86 \pm 0.94(1.02)$ & $\begin{array}{l}36.74 \pm 2.31 \\
(<0.82)\end{array}$ & $4.06 \pm 0.04(2.84)$ \\
\hline U87MG & - & $36.70 \pm 2.12$ & - & - & $29.81 \pm 1.88$ & - & $1.06 \pm 0.03$ \\
\hline U87MG $\triangle E G F R$ & $\begin{array}{l}20.59 \pm 1.87 \\
(<0.51)\end{array}$ & $24.42 \pm 1.95(0.67)$ & - & - & $18.02 \pm 1.34(0.60)$ & - & $6.11 \pm 0.04(5.76)$ \\
\hline HepG2 & - & $\begin{array}{l}23.15 \pm 1.97 \\
(<0.58)\end{array}$ & - & - & $\begin{array}{l}23.46 \pm 1.95 \\
(<0.59)\end{array}$ & - & $1.41 \pm 0.12(<0.04)$ \\
\hline
\end{tabular}

AML12

${ }^{a}$ The degree of resistance was determined as the ratio of $\mathrm{IC}_{50}$ value in the resistant divided by the $\mathrm{IC}_{50}$ in the sensitive cell line; AML12 was used as the corresponding resistant counterpart for HepG2. 4: galanal A; 5: galanal B; 8: naringenin; 9: kaempferol-3,7,4'-trimethylether; (-): $>40 \mu \mathrm{gg} / \mathrm{mL}$. 
displayed better collateral sensitivity of MDR cell lines compared to doxorubicin. The use of natural products to fight multidrug resistance is an attractive strategy in chemotherapy [37-39]. P-gp-expressing CEM/ADR5000 as well as p53 knock out HCT116 $\left(p 53^{-/}\right)$and BCRPexpressing U87MG. $\triangle E G F R$ cells were less cross-resistant towards the best samples namely $A$. arundinaceum and compound 8 than towards the positive drug, doxorubicin, highlighting their possible therapeutic potential in the fight against multidrug resistance. This report also highlights the importance of the plants of the genus Aframomum as potential source of cytotoxic compounds. The results obtained collaborate with previous investigations. In effect, Aframomum melegueta previously inhibited the proliferation of the leukemia ADR5000 cell lines with a reported $\mathrm{IC}_{50}$ value of $7.80 \mu \mathrm{g} / \mathrm{mL}$ [5]. Also, naringenin (8) has shown cytotoxicity in various human cancer cell lines and induced apoptosis via a transient induction of caspase-3/CPP32 activity, in the human promyeloleukemia cell line HL-60 [40-42]. The moderate cytotoxicity of galanals $\mathrm{A}\left(4 ; \mathrm{IC}_{50}\right.$ of $18 \mu \mathrm{M}$ or $\left.5.62 \mu \mathrm{g} / \mathrm{mL}\right)$ and $\mathrm{B}(5$; $\mathrm{IC}_{50}$ of $32 \mu \mathrm{M}$ or $12.21 \mu \mathrm{g} / \mathrm{mL}$ ) towards human T lymphoma Jurkat cells was also reported [29].

\section{Conclusions}

Finally, this work provides further evidence of the cytotoxic potential of Aframomum species and highlights the good activity of Aframomum arundinaceum on sensitive and drug-resistant cancer cell lines. Bioactive constituents of this plant include galanals $\mathrm{A}$ and $\mathrm{B}$, naringenin and kaempferol-3,7,4'-trimethylether. Aframomum arundinaceum could be explored in more detail in the future to develop novel anticancer drugs against sensitive and resistant phenotypes.

\section{Competing interests}

The authors declare that they have no competing interests.

\section{Authors' contributions}

VK, PYA and ATM carried out the study; PYA, ATM, SOY, RM, GDWF and BTN contributed to plant's collection, compound's isolation and/or identification. VK and TE designed the experiments. VK wrote the manuscript; TE supervised the work, provided the facilities for the study. All authors read and approved the final manuscript.

\section{Acknowledgements \\ VK is very grateful to the Alexander von Humboldt foundation for an 18 months' fellowship in Germany through the "Georg Foster Research Fellowship for Experienced Researcher" program; PYA is grateful to the Network of Analytical and Bioassay Services in Africa (NABSA) for a 2-months maintenance grant to the University of Botswana.}

\section{Author details}

'Department of Pharmaceutical Biology, Institute of Pharmacy and Biochemistry, University of Mainz, 55128 Mainz, Germany. ²Department of Chemistry, Faculty of Science, University of Botswana, Francistown, Botswana. ${ }^{3}$ Departments of Biochemistry, Faculty of Science, University of Dschang, Dschang, Cameroon. ${ }^{4}$ Departments of Organic Chemistry, Faculty of Science, University of Yaoundé I, Yaoundé, Cameroon. ${ }^{5}$ Department of Chemistry,
Higher Teachers' Training College, University of Yaoundé I, Yaoundé, Cameroon.

Received: 4 July 2014 Accepted: 16 September 2014 Published: 19 September 2014

\section{References}

1. Jemal A, Bray F, Center MM, Ferlay J, Ward E, Forman D: Global cancer statistics. CA-Cancer J Clin 2011, 61(2):69-90.

2. Chen Z, Zhang L, Xia L, Jin Y, Wu Q, Guo H, Shang X, Dou J, Wu K, Nie Y, Fan D: Genomic analysis of drug resistant gastric cancer cell lines by combining mRNA and microRNA expression profiling. Cancer Lett 2014, 350(1-2):43-51.

3. Marchini S, Marrazzo E, Bonomi R, Chiorino G, Zaffaroni M, Weissbach L, Hornicek FJ, Broggini M, Faircloth GT, D'Incalci M: Molecular characterisation of two human cancer cell lines selected in vitro for their chemotherapeutic drug resistance to ET-743. Eur J Cancer 2005, 41(2):323-333.

4. Kuete V, Mbaveng AT, Tsaffack M, Beng VP, Etoa FX, Nkengfack AE, Meyer J J, Lall N: Antitumor, antioxidant and antimicrobial activities of Bersama engleriana (Melianthaceae). J Ethnopharmacol 2008, 115(3):494-501.

5. Kuete V, Krusche B, Youns M, Voukeng I, Fankam AG, Tankeo S, Lacmata S, Efferth T: Cytotoxicity of some Cameroonian spices and selected medicinal plant extracts. J Ethnopharmacol 2011, 134(3):803-812.

6. Kuete V, Sandjo L, Nantchouang Ouete J, Fouotsa H, Wiench B, Efferth T: Cytotoxicity and modes of action of three naturally occuring xanthones (8-hydroxycudraxanthone G, morusignin I and cudraxanthone I) against sensitive and multidrug-resistant cancer cell lines. Phytomedicine 2013, 21(3):315-322

7. Kuete V, Sandjo LP, Kwamou GM, Wiench B, Nkengfack AE, Efferth T: Activity of three cytotoxic isoflavonoids from Erythrina excelsa and Erythrina senegalensis (neobavaisoflavone, sigmoidin $\mathrm{H}$ and isoneorautenol) toward multi-factorial drug resistant cancer cells. Phytomedicine 2014, 21(5):682-688.

8. Goldstein L, Galski H, Fojo A, Willingham M, Lai S-L, Gazdar A, Pirker R, Green A, Crist W, Brodeur GM, Lieber M, Cossman J, Gottesman MM, Pastan I: Expression of multidrug resistance gene in human cancers. $J$ Natl Cancer Inst 1989, 81(2):116-124.

9. Kuwazuru Y, Yoshimura A, Hanada S, Ichikawa M, Saito T, Uozumi K, Utsunomiya A, Arima T, Akiyama S-l: Expression of the multidrug transporter, P-glycoprotein, in chronic myelogenous leukaemia cells in blast crisis. Brit J Haematol 1990, 74(1):24-29.

10. Tane P, Tatsimo S, Ayimele G, Connolly J: Bioactive metabolites from Aframomum species. In 11th NAPRECA Symposium Book of Proceedings. Antananarivo, Madagascar: NAPRECA; 2005:214-223.

11. Dzoyem JP, Guru SK, Pieme CA, Kuete V, Sharma A, Khan IA, Saxena AK, Vishwakarma RA: Cytotoxic and antimicrobial activity of selected Cameroonian edible plants. BMC Complement Altern Med 2013, 13:78,

12. Djeussi DE, Noumedem JA, Seukep JA, Fankam AG, Voukeng IK, Tankeo SB, Nkuete $\mathrm{AH}$, Kuete $\mathrm{V}$ : Antibacterial activities of selected edible plants extracts against multidrug-resistant Gram-negative bacteria. BMC Complement Altern Med 2013, 13(1):164.

13. Seukep JA, Fankam AG, Djeussi DE, Voukeng IK, Tankeo SB, Noumdem JA, Kuete $\mathrm{AH}$, Kuete $\mathrm{V}$ : Antibacterial activities of the methanol extracts of seven Cameroonian dietary plants against bacteria expressing MDR phenotypes. Springerplus 2013, 2:363.

14. Thomas D, Thomas J, Bromley W, Mbenkum F: Korup ethnobotany survey, final report to: The World Wide Fund for Nature. In Weyside Park, Godalming, Surrey, UK: Penda House; 1989.

15. Ndukwu B, Ben-Nwadibia N: Ethnomedicinal aspects of plants used as spices and condiments in the Niger delta area of Nigeria. Port Harcourt, Nigeria: University of Port Harcourt PMB; 2010

16. Iwu M: Handbook of African Medicinal Plants. Boca Raton, FL: CRC Press; 1993.

17. Duker-Eshun G, Jaroszewski JW, Asomaning WA, Oppong-Boachie F, Olsen CE, Christensen SB: Antiplasmodial activity of labdanes from Aframomum Iatifolium and Aframomum sceptrum. Planta Med 2002, 68(7):642-644.

18. O'Brien J, Wilson I, Orton T, Pognan F: Investigation of the Alamar Blue (resazurin) fluorescent dye for the assessment of mammalian cell cytotoxicity. Eur J Biochem 2000, 267(17):5421-5426. 
19. Kuete V, Tchakam PD, Wiench B, Ngameni B, Wabo HK, Tala MF, Moungang ML, Ngadjui BT, Murayama T, Efferth T: Cytotoxicity and modes of action of four naturally occuring benzophenones: 2,2',5,6'-tetrahydroxybenzophenone, guttiferone $\mathrm{E}$, isogarcinol and isoxanthochymol. Phytomedicine 2013, 20(6):528-536.

20. Kimmig A, Gekeler V, Neumann M, Frese G, Handgretinger R, Kardos G, Diddens $\mathrm{H}$, Niethammer D: Susceptibility of multidrug-resistant human leukemia cell lines to human interleukin 2-activated killer cells. Cancer Res 1990, 50(21):6793-6799.

21. Efferth T, Sauerbrey A, Olbrich A, Gebhart E, Rauch P, Weber HO, Hengstler JG, Halatsch ME, Volm M, Tew KD, Ross DD, Funk JO: Molecular modes of action of artesunate in tumor cell lines. Mol Pharmacol 2003, 64(2):382-394.

22. Gillet J, Efferth T, Steinbach D, Hamels J, de Longueville F, Bertholet V, Remacle J: Microarray-based detection of multidrug resistance in human tumor cells by expression profiling of ATP-binding cassette transporter genes. Cancer Res 2004, 64(24):8987-8993.

23. Doyle LA, Yang W, Abruzzo LV, Krogmann T, Gao Y, Rishi AK, Ross DD: A multidrug resistance transporter from human MCF-7 breast cancer cells. Proc Natl Acad Sci U S A 1998, 95(26):15665-15670.

24. Kuete V, Sandjo L, Wiench B, Efferth T: Cytotoxicity and modes of action of four Cameroonian dietary spices ethno-medically used to treat Cancers: Echinops giganteus, Xylopia aethiopica, Imperata cylindrica and Piper capense. J Ethnopharmacol 2013, 149(1):245-253.

25. Kuete V, Fankam AG, Wiench B, Efferth T: Cytotoxicity and modes of action of the methanol extracts of six Cameroonian medicinal plants against multidrug-resistant tumor cells. Evid Based Complement Alternat Med 2013, 2013:285903.

26. Kuete V, Tankeo SB, Saeed ME, Wiench B, Tane P, Efferth T: Cytotoxicity and modes of action of five Cameroonian medicinal plants against multi-factorial drug resistance of tumor cells. J Ethnopharmacol 2014, 153(1):207-219.

27. Kamdem Wabo H, Tane P, Connolly J: Diterpenoids and sesquiterpenoids from Aframomum arundinaceum. Biochem Syst Ecol 2006, 34:603-605.

28. Morita $\mathrm{H}$, Itokawa $\mathrm{H}$ : Cytotoxic and antifungal diterpenes from the seeds of Alpinia galanga. Planta Med 1988, 54(2):117-120.

29. Miyoshi N, Nakamura Y, Ueda Y, Abe M, Ozawa Y, Uchida K, Osawa T: Dietary ginger constituents, galanals $\mathrm{A}$ and $\mathrm{B}$, are potent apoptosis inducers in Human T lymphoma Jurkat cells. Cancer Lett 2003, 199(2):113-119.

30. Bousetla A, Konuklugil B, Bouacida S, Zellagui A, Rhouati S, Akkal S: Phytochemical study of Algerian Foeniculum vulgare Mill (Apiaceae). Der Pharmacia Lettre 2013, 5(6):9-11

31. Rogerson FSS, Azevedo Z, Fortunato N, de Freitas VAP: 1,3Dimethoxybenzene, a newly identified component of port wine. J Sci Food Agric 2002, 82(11):1287-1292

32. Nilupa R, Lalith J, Noriyuki H, Yoshinori F: Chemical constituents of the fruits of Artocarpus altilis. Biochem Syst Ecol 2007, 36:323-325.

33. Pizzolatti M, Verdi L, Brighente I, Neiva T, Schripsema J, Braz Filho R: Anticoagulant effect and constituents of Baccharis illinita. Nat Prod Commun 2006, 1(1):37-42

34. Suffness M, Pezzuto J: Assays related to cancer drug discovery. London: Academic Press; 1990

35. Boik J: Natural compounds in cancer therapy. Minnesota USA: Oregon Medical Press; 2001.

36. Brahemi G, Kona FR, Fiasella A, Buac D, Soukupova J, Brancale A, Burger AM, Westwell $A D$ : Exploring the structural requirements for inhibition of the ubiquitin E3 ligase breast cancer associated protein 2 (BCA2) as a treatment for breast cancer. J Med Chem 2010, 53(7):2757-2765.

37. Efferth T: The human ATP-binding cassette transporter genes: from the bench to the bedside. Curr Mol Med 2001, 1(1):45-65.

38. Gottesman MM, Ling V: The molecular basis of multidrug resistance in cancer: the early years of P-glycoprotein research. FEBS Lett 2006, 580(4):998-1009

39. Gillet JP, Efferth T, Remacle J: Chemotherapy-induced resistance by ATP-binding cassette transporter genes. Biochim Biophys Acta 2007, 1775(2):237-262

40. Chen YC, Shen SC, Lin HY: Rutinoside at C7 attenuates the apoptosisinducing activity of flavonoids. Biochem Pharmacol 2003, 66(7):1139-1150.
41. Kanno S, Shouji A, Asou K, Ishikawa M: Effects of naringin on hydrogen peroxide-induced cytotoxicity and apoptosis in P388 cells. J Pharmacol Sci 2003, 92(2):166-170

42. Wang BD, Yang ZY, Wang Q, Cai TK, Crewdson P: Synthesis, characterization, cytotoxic activities, and DNA-binding properties of the La(III) complex with Naringenin Schiff-base. Bioorg Med Chem 2006, 14(6):1880-1888

doi:10.1186/1472-6882-14-340

Cite this article as: Kuete et al:: Cytotoxicity of four Aframomum species (A. arundinaceum, A. alboviolaceum, A. kayserianum and A. polyanthum) towards multi-factorial drug resistant cancer cell lines. BMC Complementary and Alternative Medicine 2014 14:340.

\section{Submit your next manuscript to BioMed Central and take full advantage of:}

- Convenient online submission

- Thorough peer review

- No space constraints or color figure charges

- Immediate publication on acceptance

- Inclusion in PubMed, CAS, Scopus and Google Scholar

- Research which is freely available for redistribution 